\title{
Quizizz as Fun Multiplying Learning Media in English Lecturing Process
}

\author{
Angga Prasongko \\ Universitas Islam Kadiri - Kediri \\ prasongkoangga90@gmail.com
}

\begin{abstract}
Indonesia has a great opportunity to use technological developments in the current $4^{\text {th }}$ industrial revolution. The opportunity is based on the fact that from the total population of Indonesia, more than half of them are active internet users. The largest group of internet users in Indonesia is at the age of students, these groups of students are in the middle to college student level. To occupy the need for technology-based learning, it is necessary to modify and have some innovations to various learning tools in learning activities. This qualitative descriptive research will discuss the use of technology-based learning media with Quizizz as an application in English learning lecturing process. This study involved students of the $1^{\text {st }}$ level of accounting study program who had passed English Class at the Universitas Islam Kadiri-Kediri (UNISKA). In general, the results of the study indicate that English lecturing process using the Quizizz is a fun and effective activity so that it is expected to continue to be used in further lecturing activities.
\end{abstract}

Keywords: Education, English Lecturing, Learning Tools, Quizizz App

\section{Introduction}

The development of technology and information in Indonesia has reached the fourth generation stage known as the industrial revolution 4.0. This revolution emphasizes the use of internet technology massively so that it presents the basic concept of automatic network connections in various sectors of human life. According to Hermann et al (2016) that interconnection (connection) is a principle design in this era of industrial revolution 4.0. Interconnection means the ability of machines, devices, sensors, and humans to connect and communicate with each other via the Internet of Things (IoT) or the Internet of People (IoP).

Education is one of the sectors affected by the development of this revolution. (Ekayati, 2018) Indonesia's education sector in the future will be more 
developed in the form of open education. This form is in the form of sharing shared learning resources between educational institutions in a network, the use of interactive information technology devices with the optimal use of internet technology in the development of learning. This situation provides an opportunity for lecturers to carry out modifications and variations in technology-based learning models to help students achieve learning goals.

One of the advances in the education sector developed to achieve learning goals is the Quizizz. This application is a learning tool that has many features for learning. This application can be accessed by teachers and students for free; this application is also easy to use. Quizizz is a game-based educational application, which brings multiplayer activities to classrooms and makes in-class exercises interactive and fun. It calls multiplayer learning media with fun activities. Using Quizizz, students can do in-class exercises on their electronic devices. Unlike other educational applications, Quizizz has game characteristics like avatars, themes, memes and music, which are entertaining in the learning process. According to Adam, (2018) about Implementing Quizizz as Game Based Learning in the Arabic Classroom The Arabic classroom by implementing Quizizz as a game based learning in the Arabic classroom of Sultan Idris Education University Malaysia. According to testing the implementation of Quizizz by researcher during the Arabic skill classroom, found that all the students were very active on the topic of research and more concentrated on the topic. And the results of the questioners show that the students displayed the position of attorney as a online teaching and assessment tool during the Arabic class. 
Quizizz also allows students to compete with each other and motivates them to study. Students take the quiz at the same time in class and see their live ranking on the leaderboard. Instructors can monitor the process and download the report when the quiz is finished to evaluate students' performance. Quizizz is an educational app that applies the concept of game fixation (MacNamara \& Murphy, 2017). The colorful interface,navatars and music provide students a similar experience as a game does. After students answer each question, Quizizz will show pictures with memes to tell whether the answer is right or wrong. This is a treat to students (Miller, 2017). Prior studies describe different ways of applying Quizizz. It can be used to organize classroom activities and prepare tests (Dean, 2017; MacNamara \& Murphy, 2017). Quzizz also can be used in flipped class lectures (Dayal, Green, \& Browne, 2016). Boulden, Hurt, and Richardson (2017) use Quizizz and other educational apps to help students recognize the difference between productive and nonproductive questions. Suo, Suo, and Zalika (2018) apply Quizizz in the Arabic classroom and find that it is effective to enhance students' learning as a game-based learning tool. Quizizz is also applied in Physics course enrolled by engineering students and is found to be effective in increasing learning outcomes and decreasing anxiety (Aşıksoy \& Sorakin, 2018). HamiltonHankins (2017) introduce Quizizz in an English Language Arts Classroom and find it has positive impact on student engagement. Using Quizizz in the accounting classroom helps stimulate students' interest and improve students' engagement (Zhao,2019). This is supported by research conducted by toward accounting students at Girard school of business, North Andover, USA. 


\section{Purpose of Quizizz application}

Quizizz is a wonderful tool similar to Kahoot in that you can make online quizzes. It is much less competitive than Kahoot and students can actually see the question on the device. All students work at their own pace and timers can be turned off. Students can make a Quizizz a homework assignment or have students complete them in class. You can easily export the resu lts into an Excel spreadsheet and the program saves the data. You can log in simply with your (Google) email address. This takes away the stress of students knowing that they are in last place. You can also create your own memes which are funny pictures. It is also very easy to make your own quizzes by building from other people's public Quizzes. It saves a lot of time in grading. (Medvedovska, et.al., 2016). Quizizz gives the opportunity to complete the quiz with music and silly "correct" or "incorrect" images drawn from popular media. These pictures with fun / funny messages are a treat. They're displayed after a question is answered to show whether it's right or wrong. Quizizz even lets you create your own (see image at right). The students can use their preloaded images or upload your own. As the teacher, once the quiz is over, you have access data and analyze reports and easy to know the reading skill of students. Teacher can see the overall class performance on a particular quiz, or the individual student breakdown as well. Quizizz also has integration with Google Classroom. So if students are using that learning management system can easily push out your quizzes to your students, and they will already be authenticated with their school emails. Some of the features of Google Classroom integration include the following: Google Classroom Integrated Reports Quizizz is definitely fun. But when everyone is answering different questions at different times, you lose a bit of 
the excitement. When a Quizizz game is over, you can review all the questions all at once, and you lose that isolation.

\section{The Implementing of Quizizz Application}

The implementing of Quizizz, According to Chandler, (2015) are :

First, Quizizz is free tool that allows teachers to quickly turn introductory and review activities into fun, multiplayer activities for students. It works on any device with a browser, and allows you to create your own activities or to use those already made by other educators. No usernames or passwords are required. Second, Quizizz To _play,' students simply go to the Quizizz site and enter the game code provided by their teacher. Once the quiz ends, teachers are provided a detailed report of student responses that can be downloaded and saved. Third, Quizziz has some unique features that most free gamification tools don't. For example, Quizizz is designed to be student-paced, rather than teacher-driven. The teacher dashboard provides excellent real-time updates of student progress, but also allows teachers to customize each learning activity. Finally, there are options that allow you to jumble the question order, decide if you want to use timers and leaderboards, and even provide a list of correct questions and answers at the end of the quiz. Quizizz injects quiz-taking with a bit of badly needed fun. Equally important, it provides teachers with excellent feedback on how their students are doing.

Based on observations did by the researcher that the Quizizz is used on English lecturing process with an E-learning model. Based on the purpose of the application, students should be fun when using the application as in the results of several studies that have been done. This underlies the idea of conducting an 
analysis to describe how the Quizizz applied as a fun learning media in English lecturing process.

\section{Method}

The subjects of this research are students of the $1^{\text {st }}$ level of accounting study program who had passed English Class in odd semester of 2020 - 2021 academic years in UNISKA. This research method is qualitative research using three instruments. They are observation, in-depth interviews and questionnaires. Data were collected from research subjects to describe how the Quizizz applied as a fun learning media in English lecturing process through observation, interviews, and questionnaires related to student response. Furthermore, the data obtained were analyzed descriptively.

\section{Result s and Discussions}

Online-based learning is a new learning method at Uniska Kediri. This is because there is a policy that requires the implementation of online learning activities. This situation makes lecturers have to adapt and be able to use various ways in learning process with new methods while remaining oriented towards learning objectives. English course is one that has applied online learning methods. English lecturer in the accounting department uses the Quizizz for English lecturing process. In detail, the description of the applied of this Quizizz is as follows:

\section{a. Online lecturing process}

Online lecturing process begins with the introduction of learning methods to students. Lecturers make learning strategies that are in accordance with the character of the learner and learning objectives based on online methods. The implementation of English lecturing process begins with introducing several 
online-based applications for learning activities. Lecture teaches English virtually using the Google Meet application, then students are asked to create an account on the agreed application for use. One of the applications that used is Quizizz. The lecturer explains the procedure for using the Quizizz and uses it for English lecturing media, including explaining the material and fun assessment activities. Students join the Quizizz to the instructions given by the lecturer while English lecturing process.

\section{b. Lecturers' perceptions}

As a lecturer, the use of appropriate learning media is a must. Lecturer considers that by applying of the Quizizz in English lecturing process increases student interaction with other students and lecturers during learning. Based on observations of students, they seem fun, interested and happy using the Quizizz, students seem to have no difficulty to operate the application setting. Lecturers also feel that Quizizz is effective, easy and fun application for English lecturing process. Quizizz is an appropriate application to be used as an effective, easy and fun online learning media in English lecturing process to achieve the goals of learning English.

\section{c. Students' Perceptions}

Questionnaires are used to measure students' perceptions to the Quizizz application applied as a fun learning media in English lecturing process. The responses obtained are on the table 1, as follows:

Table 1. Quizizz student's Survey Result

\begin{tabular}{|c|l|c|c|c|}
\hline \multirow{2}{*}{ No } & Survey Question & \multicolumn{3}{|c|}{ Percentage Number } \\
\cline { 3 - 5 } & & Agree & Natural & Disagree \\
\hline 1 & Using Quizizz is easy & $90.0 \%$ & $10.00 \%$ & $0.00 \%$ \\
\hline
\end{tabular}




\begin{tabular}{|c|l|c|c|c|}
\hline 2 & Using Quizizz doing in-class exercises is fun. & $90.0 \%$ & $6.70 \%$ & $3.30 \%$ \\
\hline 3 & $\begin{array}{l}\text { Using Quizizz is effective in enhancing my engagement in } \\
\text { the classroom }\end{array}$ & $82.7 \%$ & $6.90 \%$ & $10.30 \%$ \\
\hline 4 & $\begin{array}{l}\text { Using Quizizz doing in-class exercises stimulates my } \\
\text { interest in study English }\end{array}$ & $86.6 \%$ & $10.00 \%$ & $3.30 \%$ \\
\hline 5 & $\begin{array}{l}\text { Using Quizizz doing in-class exercises helps me review the } \\
\text { topic }\end{array}$ & $90.0 \%$ & $6.70 \%$ & $3.30 \%$ \\
\hline 6 & The ranking list in Quizizz motivates me to study & $83.3 \%$ & $10.00 \%$ & $6.70 \%$ \\
\hline 7 & Using Quizizz helps me concentrate in class. & $90.0 \%$ & $6.70 \%$ & $3.30 \%$ \\
\hline 8 & $\begin{array}{l}\text { Doing in-class exercises using Quizizz is more helpful in } \\
\text { my learning than doing in-class exercises on paper. }\end{array}$ & $86.6 \%$ & $10.00 \%$ & $3.30 \%$ \\
\hline 9 & $\begin{array}{l}\text { Doing in-class exercises using Quizizz helps me know my } \\
\text { classmate }\end{array}$ & $63.3 \%$ & $23.30 \%$ & $13.30 \%$ \\
\hline 10 & I would like to use Quizizz more in the future. & $86.6 \%$ & $10.00 \%$ & $3.30 \%$ \\
\hline
\end{tabular}

Source: Modified from (Zhao,2019)

From the result we can conclude that almost students agree that Quiziz is an easy interactive game for education which is make them fun and enjoy on the activity. These statements include the number of students done by the Quizizzs. By using Quizizz in English learning process the students are motivated and get interested to study English also they like to use it more in the future. Quizizz help the students to know one and each other in online learning process by doing the interaction multiplying activity.

\section{Conclusions}

The Quizizz applied as learning media in English lecturing process for accounting study program students of UNISKA conducted by online-based learning process. The Quizizz is used as a teaching-learning media to distribute English topic material and assessment as fun activities. The Quizizz is used by students while English lecturing process based on lecturer instructions. Based on the lecturers' perceptions, concluded that Quizizz is as Fun Multiplying Learning Media in English Lecturing Process. Furthermore, students as English learners who applied the Quizizz agree that Quizizz as Fun is Multiplying Learning Media in English Lecturing Process. This shows that lecturers and students have a positive perception of the applied of the Quizizz in learning English for accounting study program students in UNISKA. In addition, lecturers and students are satisfied with the learning process through 
this method. This shows that this method is effective to be applied for English lecturing process.

\section{References}

Boulden, D. C., Hurt, J. W., \& Richardson, M. K. (2017). Implementing digital tools to support student questioning abilities: A Collaborative Action Research Report. i.e.: inquiry in education, 9(1).

Chandler, Curtis. (2015, juli 22). Four tools to help gamify your classroom. Middleweb.

Dean, H. (2017). Creating critical readers: connecting close reading and technology. The California Reader. 50(4), 8-11.

Ekayati, Rini. (2018). Implementasi Metode Blended Learning Berbasis Aplikasi Edmodo. Jurnal EduTech Vol. 4 No.2 September 2018

Ellis, Robert A., Paul Ginnsb and Leanne Piggott. (2009). E-learning in higher education: some key aspects and their relationship to approaches to study. Higher Education Research \& Development, Vol. 28, No. 3, June 2009, 303-318.

Hamilton-Hankins, O. J. (2017). The impact of technology integration on the engagement levels of ten second grade students in an English Language Arts classroom. University of South Carolina Scholar Commons.

Kim, Kyong-Jee and Curtis J. Bonk. (2006). The Future of Online Teaching and Learning in Higher Education. Educause Quarterly,Number 42006.

MacNamara, D., \& Murphy, L. (2017). Online versus offline perspectives on gamified learning. GamiFIN Conference, University Consortium of Pori, Finland.

Medvedovska D., Skarlupina Y., \& Turchyna, T. (2016). Integrating online educational applications in the classroom. European Humanities Studies: State and Society, 4, 145-156.

Miller, M. Game Show Classroom: Comparing Kahoot!, Quizizz, Quizlet Live \& Gimkit. (2016).

Nanda, Siti Reski. (2018). The Use Of Quizizz Application in Improving Students' Reading Comprehention Skill at Smkn 3 Takalar. Thesis of English Education Departement Faculty of Teacher and Training Education Muhammadiyah University of Makasar. 
Suo, Y. M., \& Suo Y. J., \& Zalika, Adam. (2018). Implementing Quizizz as game based learning in the Arabic classroom. European Journal of Social Science Education and Research, 12(1), 208-212.

Zhao, Fang. (2019). Using Quizizz to Integrate Fun Multiplayer Activity in the Accounting Classroom. International Journal of Higher Education Vol. 8, No.1:2019. 